\title{
A Study on Sports Training Management System of Some Universities in Chengdu
}

\author{
Xiaoyuan Wen \\ Chengdu Sports University
}

\begin{abstract}
Knowledge and talents are the main driving forces for social advance and country development. In today's world, the competition between economic, technology, national defense and other fields are ultimately the talents competition. Meanwhile, the competition between sports talents in our country become increasingly fierce and the demand for it also grow with each passing day. There are five universities in Chengdu take the response to train professional sport talents for China as well except Chengdu Sport University, which are Sichuan University, Southwestern University of Finance and Economics, Southwest University for Nationalities, University of Electronic Science and Technology of China and Sichuan Normal University. The current sport training teaching modein these universities should draw on each other's strength and complement and push the sport teaching system reform to break the existing problem. So, in-depth exploration and study on how to strengthen the connection between sport training teaching system of these five universities has become their key task. The development of sports talents resources mainly from universities education. Through teaching process, universities can develop the sports talents resources, however, sports teaching is conducted within the talents training mode. Whether the training mode is reasonable or not is directly relates to the quality of graduates, and also the quality of sports talents resources development in some way.
\end{abstract}

Keywords-universities; talents training; sport training; management system

\section{INTRODUCTION}

With the setting-up and improvement of the system of socialist market economy of our country, the enact and implement of "the National Fitness Program" and "Program of Striving for Olympic Glory", it provide opportunities for our country's long-term sport enterprise development, promote sports public participation. Therefore, we need more professional sports talents to guide people how to join sports, high-level athletes are needed, besides, high-level coaches and senior sports managers and high-quality sports researchers are needed as well, consequently, the special training for these talent people is become important. Furthermore, the current sport training management system situation in the five universities certainly will affect the height of sports training majors, the operation of sport training management system, in the same time it plays a important role in helping our country to develop amounts of excellent athletes and coach and promoting the development of sport enterprise. Therefore, proceed study research on the sport majors training methods of these five universities in Chengdu is of great strategic significance in quicken the cultivation of professional sport training talents for our country.

\section{THE SETTING-UP OF SPORTS TRAINING MAJOR AND THE IMPACTS ON CHENGDU'S FIVE UNIVERSITIES DURING ITS DEVELOPMENT}

The major sports training is a important major to the education of sports specialty, it has a winding development process. It was first established in 1957 in Beijing Sports College, after that, it cultivated amounts of qualified coaches and high-level athletes and relieve the problems that coach shortages and athletes lack skills at the time of our founding.

Since the founding of sports training major, the training goal of the five universities has been adjusted with the continuous development of our country sports enterprise. At that time, influenced by all levels underdeveloped competitive sports training teams, these universities faced the problems to solve the retired athletes wanted to continue to learning but can hardly got entrance. During the early day of the sports training foundation in the five university, sports department students are mainly from the athletes, and the initial purpose was to solve the shortage of the coaches and cultivated high-level athletes and coaches. Under the condition of slow social economic development and extremely short of material conditions, the five universities were focus on teaching, and training targets are coaches and specialized teachers. And with the development of economy, the abundance of material conditions, these five universities start to pay attention to the cultivation of the scientific researchers, the training goals of sports training increase a tendency to develop "researchers". Later, in quite a long time, influenced by the competitive sports, sports training major established another goal, which is the principle of "cultivating excellent athletes". Later as proposing and popularization of quality education, training major was high light the characteristics of a comprehensive, integrated, and particularity.

\section{THE TRAINING SYSTEM OF SPORTS TRAINING MAJORS IN CHENGDU’S FIVE UNIVERSITIES}

\section{A. The current analysis of training goals}

A certain training goal is play a very important role teaching process. It not only can help to set-up a training scale, but only around the goal can the course system be 
established. So, every major in the course of setting a certain goal must have a integrate purpose. So far, the diversity of the five universities is harm to sports training sound development and every major should take this account.

Training goal is means those people they are going to training which are in different levels, with different types and under different majors or the direction of talents, scale are need rapidly economy growth, sports can move toward marketization and industrialization. As the social demand for sports talents unceasingly increased, in order to make those talents adapt to the society and service the society better, it is necessary for the five universities to reform the talents training mode to meet the social development. This paper analyzed the current training goal of sports training major, at the same time to come up bold ideas for talent training mode reform, the training of talents to keep pace with the times, with strong comprehensive ability, innovation, thick foundation, wide scope and high quality, in the direction of research and application talents to develop Sichuan higher sports colleges and universities sports training major.

The sports training major of the five universities in Chengdu, their training goal has distinctive positioning and direction, and diversified training goal, in this case, it need to work in a large professional range and make rational and orderly training goal planning, so as to cultivate more suitable sports talents for social demand, to satisfied the need of our country that move from a great sports country to a power one. From the five universities of Chengdu, the positioning of the training goal in the school sports training teaching plan, due to the different characteristics and the actual situation of each school, and also different training goal level. So, at present, the academic circles calls for a reasonable training goal orientation has been growing.

Sports training major's training goal positioning of the five universities in Chengdu must first tightly connect to the needs of society, must be also according to the school and the basic characteristics of students to their own conditions to revise. Inaccurate positioning, direction too narrow are mainly performing in they can not well revised according to the social demand, the current social demand for sports training major talents is multi-level and wide field, but through the current training goal setting in the five universities of Chengdu ,it still mainly limited in school sports, which is often confused with sports education department, can not give full consideration to the reality, reflected in can not according to the characteristics of each universities, the actual condition and the characteristics of the students to positioning the training goal. Therefore, how to orientation training goal reasonably, universities still have to do in-depth study.

\section{B. The present situation of Chengdu 's five colleges sports training curriculum}

The implementation of the course is mainly to achieve the objective, so the course's setting is more important.
However, the five universities of Chengdu sports training professional personnel training curriculum is not optimistic, previously the main attaches great importance to the professional training course on schools, putting forward along with the quality education and the teaching content and course system reform facing within 21st century the project research, promote the sports training in colleges and universities personnel training curriculum of further change, to a more reasonable development of curriculum.

The cultivation of the talent, the guarantee is the quality, the characteristic is the key, in today's society to talented person's demand is, multi-tiered and wide-ranging the request which must have the characteristics of talent cultivation. Characteristics of talents depends on its knowledge structure and knowledge structure is closely related to the curriculum, and it can be said that the talent is a reflection of the curriculum. Since sports training curriculum has been in the process of groping, this article summarizes the research achievements of scholars in our country, combined with the five universities of current sports training curriculum. And we have found the following questions:

(1) The course content is relatively old, less reflections of the new achievements in the field of sports training, new changes; value theory, light practice teaching link, is not conducive to cultivating students' innovation ability.

(2) The curriculum category is monotonous, simple, lack of dynamic, developmental, holistic scientific methods and development trend, etc.

(3) To cultivate the overall abilities and innovative spirit of content, the curriculum system are unfavorable to the cultivation of students' comprehensive quality.

(4) Too large proportion of the compulsory courses ,opposite with the elective courses, and in the one-sided emphasis on classroom teaching organization form, making the whole course structure appears more rigidity and elasticity insufficient, limit the students' free elective and autonomous learning.

(5) Interdisciplinary course selection is too little, greatly reduced the students' subject range, limit the flexibility of students' course selection and knowledge structure.

\section{CONCLUSION}

1) The five universities in Chengdu sports training curriculum's training goal has been aimed at training athletes, coaches and scientific researchers and special teachers; Training target of development is constantly changing based on the needs of the society development and make timely generation changes, which has been developing gradually from simplification to diversification ,the talents' knowledge, ability and quality structure has been changed; Professional course of evolution can be divided into a preliminary stage, stagnant stage, recovery stage of development and the deepening of the basic construction stage, standardization development stage and development stage. 
2) the five universities of Chengdu sports training professional personnel training is affected by the different regional environment, have different training goal orientation, lack of relative unity; Sports training courses and physical education major are wildly divergent, lack of innovation, no outstanding professional characteristic; Curriculum resource utilization is insufficient, the training students' learning enthusiasm didn't risen, poor basic learning foundation; Teachers lack of professional experience, teacher's uneven distribution, the lack of full-time teachers, the teachers team construction is unreasonable and teaching management lack of flexibility.

3) The model construction of the guiding ideology of this research should reflect "education must face modernization, the world and the future" of the spirit of the times to absorb domestic and foreign education and the successful experience of the reform, change relatively old teaching contents and methods, perfecting the higher colleges and universities of Chengdu sports training professional personnel training mode, to meet the needs of era, reflect the characteristics of sports training; The curriculum should embody the principle of overall optimization principle, combining the unity and diversity, comprehensive and systemic; Talents training goal orientation should reflect the two aspects of school and social ; According to the five universities of Chengdu sports training student's characteristics and carry out the teaching management and formulate the training target which suit for the each training major in colleges, widening specialty caliber, to reposition the talent training goal, sets up the sports training professional talents of lifelong physical education concept, vigorously implement the curriculum reform, strengthen the cultivation of students' comprehensive ability, establish a scientific and reasonable evaluation system.

\section{SUGGESTIONS}

4.1 Suggesting that the competent department of education in Sichuan province on the basis of investigation and survey and according to the five universities of Chengdu sports training of practical and social demand and the characteristics of students, develop the province's talent training guidelines as soon as possible, on this basis, according to the actual circumstance of the school study and formulate suitable for the characteristics of the school sports training personnel training mode, to further improve the teaching quality of education.

4.2 suggesting the five colleges and universities should make full use of education teaching resources, exert its advantages, at the same time, by introducing professional people or provide teachers' further education, etc from these channel to develop the group of teachers. Change the teaching methods, fully mobilize the enthusiasm and initiative of student learning ability, teach students in accordance with their aptitude according to different students, implement credit system or being flexible credit system, guarantee the quality of personnel training.

4.3 suggesting that five universities attach great importance to the quality of our students to the cultivation the students from all perspectives, but cultivate should previously consider what the society will demand, on the premise of social demand and cultivate real talents for the society needs.

4.4 In this study of the personnel training mode is established on the basis of investigation and research, it is on the current sports training professional personnel training in colleges and universities of Sichuan province has a certain practicability and scientificity, but with the continuous development of society, colleges and universities of Sichuan province sports training professional personnel training mode should be followed by the corresponding modification and further perfect according to the actual circumstance of the schools.

\section{REFERENCES}

[1] Liu Jingming et al. The transition period Chinese social education . Liaoning: Liaoning Education Press, 2004

[2] Tian. Sports training theory. Beijing: People's sports press, 2000

[3] Tian Maijiu, Wu Fu congruent. Sports training and scientific exploration . Beijing: the people's sports press.1988.

[4] Yang Shuan, Zhang Xiaopeng. On the China table tennis team of scientific training. Sports science, 2000, 20 (2): 30-34.

[5] Shi Kangcheng. Preparation for the 2004 Athens Olympic Games, scientific research and service. sports science, 2004, 24 (12): 7-11.

[6] Mao Peng. The unitary training theory. sports and science, 2003, (4): 5-10.

[7] Tao. In journal, . competition -- exercise training in the field of our scientific understanding of Xi'an Institute of physical education of school 2007, 24(4).

[8] Good. On the sport training structure . Journal of Beijing Sport University, 2009, 32 (10)

[9] Wang Kangle. Discussion on the new discipline of sports to create . sports science, 1998, 18 (6): 9-11.

[10] Yuan Zhen Lu.21 century challenge of sports social science and the expected . 1997, 18 (4): 8

[11] Xi Yubao. Sports science system . Journal of Shandong Sports Institute and its position in modern science, the 2000 '16 (4): 9-12.

[12] Zhang Yan. Classification of sports science system . Harbin journal, 1992 (2): 14-16.

[13] Wang Borong. In law on "from sports science system" (Third Edition) revised . Journal of Beijing Sport University, 1998, 21 (1): 19-23. 